\title{
Socio-Economic Upliftment through English Language in Nepal
}

Ashok Sapkota, Lecturer

Kathmandu Shiksha Campus

\begin{abstract}
This article tries to focus on the role of English language in Nepal to uplift socioeconomic status tracing the shifts from historical practices, trends on academics, reviewing the status from policy practices and research trends. It tries to present the personal stories of learning English of professionals based on secondary source and reflecting the context of students from Nepal who desire to learn English. It tries to highlight the further suggestions and assumptions from Nepalese context in which role of English is studied in the socio-economic benefits.
\end{abstract}

Keywords: economic, technology, policies, research and marginalized

\section{Historical transitions-english language in nepal}

The development of English language traces back to $17^{\text {th }}$ century, when King Pratap Malla ruled Kathmandu. However, it was used with very limited purpose (Awasthi,1979). Likewise, King Prithivi Narayan Shah, used English on spying missionaries on supplying information to East-India Company as a business enterprise (Awasthi, ibid..., pp.1-4). This shows that the use of English began centuries back for business purpose. Basically after visit to Britain, Prime Minister Jung Bahadur Rana established English education system under Durbar School (Bhattarai, 2006) at Thapathali, on October 1853 A.D. He hired Bengali or English tutors to teach the Rana children. Chandra Shumsher adopted English language for higher education and opened Tribhuvan-Chandra College in 1918 AD (Khaniya, 2007, p.117). The oldest Nepali university, Tribhuvan University established a century later-1959 AD and presently there are twelve other universities in existence. Under National Education System Plan-1971, institute of education, TU started B.Ed programme as a form of English teaching (Awasthi, 2009). In present context, English functions as a foreign language in Nepal. When we look at the data regarding the use of English, Crystal (2003) mentions that people are regularly exposed to is 5, 927, 000. These reviews imply that the English language was used in the different times in policies or practice in direct or indirect form. 


\section{Rethinking the status of english as socio-economic upliftment}

As we look over the historical shifts, the focus on the English language since Rana and Shah Dynasty was taken as a means of social reputation, where the people who had a limited access to the English language like Rana families learnt it as a means of social upliftment. In academics, the establishment of Tribhuvan University and introduction of English courses in different levels, particularly as compulsory course in Proficiency Certificate Level and Bachelors' degree and optional in Masters' degree can be taken as the positive use of the English language as a social prosperity. In the ancient times, the demand on majoring in English, particularly in proficiency level, Bachelors' and masters' degree was in the higher range. A good example can be taken with the high number of enrollment in choosing English as major subject in the Tribhuvan University affiliated campuses in general at all levels and the student's enrollment in masters' degree at University Campus, Kirtipur in particular. Likewise, the role of the English language played a significant role in rapid growth of technology, world international trade, mass media, conferences, advertising, diplomacy, web, books and newspapers. This growing use of English shows that fluency in English, or at least the capacity to score high marks in the English examinations, is fundamentally associated with the life chances of many individuals and the economic survival in many developing countries (Martin and Lomperis, 2002 as in Farrell and Giri, 2011). On the other side, the different plans and policies, such as National Education System (NES)-1953 AD, All Round National System Plan (ARNSP)-1961 AD, National Education System Plan (NESP)- 1971 AD and National Education Commission (NEC)-1991 laid a due focus on academic sector. Hence, English as a foreign language played as a crucial element in the skill-set necessary for successful participation in 21st century Nepalese society. The English language has played a role as a language for international development' (Seargeant \& Elizabeth, 2011) even in the context of Nepal.

Thus, the importance of the English language has become universal today in the different forms. Undoubtedly, it has been widely used in the present day. Without the knowledge of the English language our access to more than half of the world would become inaccessible. There are few negative impacts of English language as well. Such as: Problem in assessment, classroom instruction and classroom delivery. However, the use of English is found dominant in the context of Nepal. Our ability to communicate with a large part of the world and do business with them would be extremely limited. 


\section{Policy and practices}

The Government of Nepal has made different provisions for the languages of Nepal in the Constitution of Nepal states that

(1) All the languages spoken as mother tongue in Nepal are the national languages of Nepal. (2) The Nepali language in the Devnagari script shall be the language of official business. (3) Not withstanding whatever is written in clause two the use of one's mother tongue in local body or office shall not be barred. The state shall translate the language used for such purposes into the language of official business for the record. (Constitution of Nepal, 2072)

Regardless to the fact that the use of English language in increasing every day, the interim constitution of Nepal has not given any official status to the English language in Nepal. It says that one's mother tongue in local body or office shall not be barred, however it does not apply to English since English is still considered to be a foreign language. Likewise, if we look at the other policies and practices, the third five year plan (1965-1970) made a provision for making teaching materials in English available in increased quantities. The fourth five year plan (1970-1975) focused on short term training to ' 1500 additional teachers in science, mathematics, English, Nepali and social sciences' and acknowledgement of the importance of English language along with Maths and Science. The eighth five year plan (1992-1997) made a provision for training for the teachers of English. The tenth five year plan (2002-2007) introduced English language subject in grade one, although the rationale for its introduction is not mentioned. National Curriculum Framework (2007) state that the medium of school level education can be Nepali or English language or both of them. School Sector Reform Plan (SSRP, 2009) focused the necessity of teaching English from grade one however the World Bank funded project called Second Higher Education Project laid no provision for English (Dahal, et al. 2013). From these data, it can be inferred that, the focus on English has significant role in the policies although it does not keep English in high priority. The use of English is limited even in the national educational policies.

\section{English as a foreign language (efl) context}

English is used as compulsory subject in schools and college and as elective in the higher education in Nepal. It is used as a second choice/alternative in official practices although it is hard to find a clear document which gives English a clear status in the 
policy. The fiscal year 2074/ 75 budget has focused English as a medium of instruction, particularly in schools and in writing in examinations.

Regarding schooling, social preference and use, it is hard to find out a particular speech community as such that uses English for day-to-day communication. The educated mass of the present day Nepal consists of people with two types of schooling background with Nepali and English mediums. The two types of schools at each level of school education namely government-aided (public/community schools) and private schools and private, community and affiliated colleges exist in the present context of Nepal. The students who study using English as a medium schools feel more convenient in higher studies. The product of English medium schools and colleges feel more comfortable in using English for personal development, and communication to modern scientific inventories such as e-mail and internet. If we observe the academic scenario comparing the two sets of data in a range of a decade of English in Nepal based on Awasthi (2003) as,

Nepal is providing education through six Universities about 1000 constituent and their affiliated colleges, some 1500 higher secondary schools and 42100 schools of which 7154 are privately run and the rest are publicly run. English occupies a prominent position in the total education system in Nepal (as cited in Bhattarai and Gautam 2007, p. 32).

\section{The recent data shows the following changes:}

Nepal is providing education through tweleve Universities; Tribhuvan University, Kathmandu University, Pokhara University, Nepal Sanskrit University, Lumbini Buddha University, Far-western University, Mid-western University and Agricultural and Foresty University and three independent institutes or academy; B.P. Koirala Institute of Health sciences, National Academy of Medical Sciences and Patan Academy of Health Sciences and the total number of schools are 34,782 in which 818 are religious schools(Madarasa, Gumba/Vihar and ashram/Gurukul). Among these, around $85 \%$ are in public schools and around 15\% private schools (Flash report, MOE, 2016)

This shows that the numbers of academic institutions are in growing number and the choice and study of English is growing on the other hand. On the other socio factors, it shows that majority of the parents first choice would be the private schools if they can have affordability and accessibility. We can easily predict the scenario of the present context to that of the context: the government has (indirectly) endorsed the English as Medium of instruction (EMOI) policy however it lacks a concrete plan. 


\section{Issues}

There are several issues on English in maintaining ones' status. The Questions emerge in the minds of many individuals regarding the role of English language; such as: Does English uplift the living status or increase in the income?, Can I get better job if I do good at four skills of English?, Will the business of English teaching and learning flourish for decades more?, Is English a basic criteria to get a job with handsome salary?, Does the knowledge in the employees increase in the trade and business industry?, Does it mean literate in English is to increase in business for the literate people?

\section{Study objectives}

The main objectives of the study is to identify the positive role of the English language as a socio-economic upliftment

\section{Methodology}

The methodology of the study was based on the survey research design. There were 20 different students studying in one of the community schools participated in the study. In addition, the main secondary sources used in the study were Crystal (2003) and Sapkota (2007) and classified job analysis on 'The Himalayan Times' (2017). The source of analysis is based on both statistical and descriptive in nature.

\section{Research practices: analysis and discussion}

This section deals with the socio economic benefits from the secondary as well as primary sources from the global practices, particularly mirroring the benefits of the English language for social benefits.

\section{Socio-economic benefits: from world to nepal}

The role of English has played a major role in the academics, particularly in schooling of the students and professionals. Here, I would like to draw some examples from secondary sources from the world based on Crystal (2003), where different professionals opined their feelings regarding the role of English as source of social upliftment. An Egyptian trainee Secretary says "When I finish learning English my pay as Secretary will be increased by nearly ten times. " Likewise a Nigerian teacher said 'After I learned English, I felt I was in touch with the international world for the very first time. ' On the same way an Indian doctor feels a strong desire to learn English as he say \& If I want to keep up to date with the latest techniques and products. I must certainly maintain my English very strongly.' A Danish student feels that 'Nearly 
everyone in Denmark speaks English. If we didn't, there wouldn't be anyone to talk to." Likewise, a Japanese business a man says, 'My Company plans big deals with Arabic world. None of us speak Arabic, and they do not know Japanese. All our plans and meetings are in English.' From the statements mentioned above, it can be inferred that the knowledge of English is beneficial not only for academic or personal growth but also for the professional development. Furthermore, being an English teacher, I tried to connect the feelings of my students (whose real name is changed); basically studying in BBA, BBS, B. Ed and higher secondary' regarding the benefits of learning English as Shyam Shrestha of grade 12 says as "I want to learn English because it is an international language". Likewise, Rupak Bhandari, BBA First Semester students says, "I want to speak in English because I need make my presentation well". A B.Ed first year student-Sita Gurung says, I need it because I can be able to get good job. A Student who just accomplished SLC says, "I need to study English because everybody likes me speaking in English, so do my parents too." A BBS Student-Shera Shrestha says, "I need to study English because I want to speak fluently in English."

Hence, English language skills are seen as a resource which will allow for participation in the financial, political economic programmes. Students want to learn in English because of the perception of members in their speech community, need, and as a tool to achieve skills in their perception.

\section{Social status: requirement to get a good job}

The role of English can be an asset to get a good job. A research funded by the UK government's Department for International Development (DFID) between 1997 and $2008 \mathrm{had}$ as its rationale the desire 'to strengthen the human resource development efforts of the Government of Bangladesh' (NCTB 2003, Hamid and Baldauf 2008, p.16) found that the English was a useful tool 'to develop Bangladeshi human capital' (Hamid 2009) by introducing communicative language teaching for English in Bangladeshi schools. To identify the context of English in Nepal, an analysis of job appointments was done in a daily "The Himalayan Times", Wednesday, Dec 11, 2013 where 26 vacancies including different 6 sections of job were analyzed; Banking, college, research institute, INGO's, automobile company, IT company, and Hydro. It was found that12 (almost half) required excellent English as a requirement. The language used in most of the appointments was 'Excellency in written and spoken English ' in job requirement section. From these review it can be analyzed that it is advantageous to the extent to have better opportunities and jobs by learn in English. 
In the same way, Sapkota (2007) did a research on role of social and economic status of marginalized group in developing English language proficiency which aimed to find out the role of the English language in uplifting their social and economic status, based on primary level children's' proficiency.

The research was conducted based on survey research design. Non-random sampling and a questionnaire was used as tool the research tool. It was found out that 26 children whose both parents were uneducated obtained below $40 \%$. It was found that the children who achieved above $80 \%, 60 \%$ and $40 \%$ were 3,10 and 12 respectively where only one of their parents was educated. So, education of the parents determines the success of their children's proficiency in English. The children' feeling towards learning English was found positive. The children who achieved above 80, 60, 40, and below 40 felt 3, 14, 22 and 35 percentage respectively easier to learn English. Although, 46 children were below $40 \%$ but out of them 35 felt easier.

The data shows that Parents' attitude towards learning English was found highly positive where $89 \%$ parents were found happy towards learning English by their children. All parents of the selected children responded that English is essential and important for their children. If they want their children to be more competitive and to get better job in future. English was viewed as an essential subject.

\section{Conclusion and reflections}

From the above description and research practices, the following reflections and suggestions can be taken into consideration which determines the status of the English language in the context of Nepal

\section{Assumption 1: English as a global language}

Global language implies a language which is not exclusively associated with a particular country and culture (i.e. the UK, the USA, etc.), but is of value because of its usefulness internationally. 'English language as a tool for better access to the world economy' (EIA 2010 as in Seargeant \& Elizabeth, 2011), Many people in the context of Nepal recall the same idea in their mind and try to gain command over it; either students or professionals to enrich their professionalism or for the parents to help in the communication or help in their children's' studies.

\section{Assumption 2: English and economic value}

Language is resource for the economic development which implies in the case of English too. A recent research conducted in Bangladesh as part of the EIA programme, for example, claims that over 80 per cent of Bangladeshis believe that knowledge 
of English will help them increase their income (BBC 2009). English is taken as a tool of economic and social advancement. Grin (2001) found that in the Swiss labour market salary premiums rise along with competence in English. Chakraborty and Kapur (2008, p.21 as in Seargeant \& Elizabeth, 2011) found that individuals who were more likely to have training in English earned significantly higher wages and gained better occupational outcomes than those who did not. In the context of Nepal, several examples can be elicited which shows that the use of English can enrich the economic value. Such as: the riksha drivers of Lumbini and Birjung, Taxi drivers of Thamel, Pokhara and Patan try to speak few words in English language or some of them such as tourist guide speak in English fluently, which help them to increase their business and grow economically.

\section{Assumption 3: English as a language for education}

For Grin (2003 as in Seargeant \& Elizabeth, 2011), 'non-market value’ of English; the social and cultural effects that are associated with the language. The role English plays as a form of 'Changing learning, changing lives' (EIA 2009c). The strong role for English in the national curriculum due to societal attitudes that equate English with education (e.g. Tembe and Norton 2008, Williams and Cooke 2002 as in Seargeant \& Elizabeth, 2011). So, English as a means of educational enhancement, e.g. English Microscholarship Programme run by Nepal English Language Teachers Association (NELTA) in Nepal has high demand in among the parents in the different areas in Nepal. The international language courses, such as IELTS, TOEFL, CELTA, DELTA, etc are learnt by huge group of learners or practitioners across the world to achieve scholarships for the further study or increase their skills in the English language.

\section{Assumption 4: English as the language of technology}

The economic competitiveness and educational advancement can be developed with the help of learning English language. It is a means of allowing access to technology -seen as facilitating learning and supporting educational change. United Nations' Millennium Development Goals (UN 2000 as in Seargeant \& Elizabeth, 2011) of universal primary education and of developing global partnerships that make available the benefits of new technologies. English and ICT education can be found in policy statements across the globe. Correlations have also been discovered between competence in English and economic development (Grin 2001, Chakraborty and Kapur 
2008). The use of technology in Nepal can be exemplified in the schools or colleges or universities where many schools are instructing their students using multimedia where English is a medium of instruction.

\section{References}

Apka House. (2017). The appointments; The Himalayan Times, Kathmandu: Author

Awasthi, J.R. (1979). A study of attitudes of different groups of people towards English language in the secondary schools of Kathmandu district. Unpublished M.Ed. thesis, Department of English Education: Tribhuvan University, Kathmandu.

Bhattarai, G. R. \& Gautam, G. R. (2007). The proposed ELT survey: Redefining the status and role of English in Nepal. Journal of NELTA: vol-12. Kathmandu: NELTA.

Bhattarai, G.R. (2006). English teaching situation in Nepal: Elaboration of the theme for panel discussion in the 40 th TESOL conference. Journal of NELTA.vol-11. Kathmandu: NELTA.

Centre of Constitutional Dialogue. (2009). The Interim constitution of Nepal, 2063. Kathmandu: UNDP.

Crystal, D. (2003). Encyclopedia of language. Cambridge: CUP.

Dahal et al., (2013). ELT policy review. Kathmandu: NELTA

Farrell, L., Singh, U. N. \& Giri, R.M. (2011). English language in south Asia. Delhi: Foundation Books

Khaniya, T.R. (2007). New horizons in education in Nepal: Kathmandu: Kishor Khaniya.

Mansoor et al.;(2009). Emerging issues in TEFL. Oxford University Press. India.

Ministry of Education. (2016). Flash report. Ministry of Education: Kathmandu

Sapkota,A.(2007).Socio-linguistic Upliftment through English language in marganilized group proficiency. Unpublished M.Ed. thesis, Department of English Education: Tribhuvan University, Kathmandu.

Seargeant, P. \& Elizabeth J. Erling (2011). The discourse of 'English as a language for international development': Policy assumptions and practical challenges In Coleman, H. Dreams and Realities: Developing Countries and the English Language (Ed.) London:British Council 